\title{
Assessment of an existing RC building before and after strengthening using nonlinear static procedure and incremental dynamic analysis
}

\author{
Amir A. Hedayat and Hakan Yalciner* \\ Civil Engineering Department, Eastern Mediterranean University, P O Box. 95, Gazimagusa, Cyprus
}

\begin{abstract}
Inadequate attention during design and construction of some of reinforced concrete (RC) buildings in Cyprus has raised questions about the performance level of these existing buildings under future earthquakes. This study aimed to assess the seismic structural response of a four story existing RC building. For this purpose, first, the weak structural elements (e.g. the not safety column-beam joints and weak columns) were detected using linear static procedure (LSP) analyses on the basis of Turkish earthquake code. Then, two different strengthening methods were examined. In the first method which is common in Cyprus, the existing building was strengthened based on LSP, using column jacketing to satisfy seismic code requirements to remove the weak elements. The second strengthening method was carried out using nonlinear static procedures (NSP) to achieve the basic safety objective (BSO) performance level described in FEMA 356. For existing and both strengthened structures, pushover curves were obtained and following FEMA 356, performance points were calculated and compared. The seismic responses of existing and strengthened buildings were also assessed using incremental dynamic analyses (IDA). Nonlinear dynamic time history analyses have been performed by using SDOF models of these buildings under action of different scales of 20 ground motion records. Then IDA curves for each earthquake have been constructed. Limit - states at each performance level have been defined and summarizing the multi - record IDA curves, $16 \%, 50 \%$ and $84 \%$ fractile curves were obtained. Since selected structure represents common existing buildings in Cyprus, probabilistic structural damage estimation fragility curves were also obtained in terms of peak ground acceleration (PGA) for each considered performance level. Results showed that the strengthening method based on the NSP to satisfy the BSO requirements is much more effective than the one based on the LSP to improve the building performance and to reduce the probability of exceeding of limit states IO, LS and CP at any seismic zone.
\end{abstract}

Keywords: Incremental dynamic analysis, performance assessment, jacketing, pushover analysis

\section{Introduction}

Earthquake engineering is based on the fact that existing buildings show inelastic response and experience permanent deformations when are subjected to design level ground acceleration. The inelastic structural response and the level of performance expected from a structure are some of the major elements that the structural engineers are interested in. The concept of Performance Based Seismic Design (PBSD) is to provide predictable and reliable performance of a structure during severe earthquakes. Performance objectives are defined in seismic documents such as ATC 40 [1] and FEMA 356 [2]. The performance levels are generally classified for structural and non-structural levels. At the structural level, the following major performance levels are used: immediate occupancy (IO), life safety (LS) and structural stability or alternative definition, collapse prevention (CP). Each structural performance level is associated with a damage state that can be observed or quantified. FEMA 356 [2] describes each of building performance levels as immediate occupancy that is described as building is safe to occupy but possibly not useful until repaired, life safety is described as building is safe during event but possibly not afterward and collapse prevention is described as building is on verge of collapse, probable total loss. To prescribe a set of performance objectives,

\footnotetext{
*Corresponding author. E-mail: hakanyalciner@hotmail.com.
} 
FEMA 356 [2] and ATC 40 [1] define different hazard levels, which define for specific probability of being exceeded in 50 years. FEMA 356 specifies design base earthquake (DBE) and maximum considered earthquake (MCE) hazard levels for probabilities of $10 \%$ and $2 \%$ in 50 years respectively. Both ATC 40 and FEMA 356 prescribe a basic safety objective (BSO) which comprises a dual-level performance objective. In FEMA 356, the BSO criterion requires LS performance level for DBE hazard level and CP performance for MCE hazard level.

There are several methods to assess the performance level of structures under earthquake ground motions [3]. Among them the nonlinear static procedure (NSP), colloquially known as "pushover analysis" and incremental dynamic analyses (IDA) are better known. In FEMA 356's NSP [2], by considering the nonlinear force-deformation behaviour of structural elements, a base shear-lateral displacement relationship is established by subjecting this model to monotonically increasing lateral forces until the displacement of a control node (the center of mass of the building's roof) exceeds a target displacement or the structure collapses. The target displacement is intended to represent the maximum displacement likely to be experienced by the structure under a selected seismic hazard level. The demands at this target displacement, element forces, story drifts, roof drift or plastic hinge rotations are then compared against a series of prescribed acceptability criteria in FEMA 356 to determine the performance level of structure at the selected hazard level. However, the NSP has become a popular tool among practicing engineers; its use is recommended for structures in which "higher mode effects" are not significant [2]. In addition, NSP neglects duration and cyclic effects, the progressive changes in the dynamic properties that take place in a structure as it experiences yielding and unloading during an earthquake, the fact that nonlinear structural behaviour is load-path dependent, and the fact that the deformation demands depend on ground motion characteristics [3].

Therefore, the structure performance would be better evaluated using IDA. Incremental dynamic analyses have recently emerged as a powerful means to study the overall behaviour of structures, from their elastic response through yielding and nonlinear response and all the way to global dynamic instability [4]. An incremental dynamic analysis involves performing a series of nonlinear dynamic analyses in which the intensity of the ground motion selected for the collapse investigation is incrementally increased until the global collapse capacity of the structure is reached [5, 6]. It also involves plotting an intensity measure (e.g. peak ground acceleration, PGA or spectral acceleration at the fundamental natural period of the structure, Sa) against a damage measure (e.g. maximum in-story drift or roof drift). In addition, fragility curves can be obtained using IDA. Fragility curve represents expected damage (e.g. IO, LS and CP) as a function of the selected ground motion intensity.

In Cyprus, the buildings are designed based on Turkish earthquake code [7]. However, inadequate attention during design and construction of some of reinforced concrete (RC) buildings has raised questions about the performance level of these existing buildings under future earthquakes. In these structures the weak columns and especially column-beam joints are the most critical regions to failure during earthquakes. This study aimed to assess the seismic structural response of a four story existing RC building. For this purpose, first, the weak structural elements (i.e. the not safety column-beam joints and weak columns) were detected using LSP analyses on the basis of Turkish earthquake code. Then two types of strengthened buildings were created. In the first strengthened building, the weak columns and joints were strengthened using ordinary jacketing technique as is common in Cyprus. The second strengthened building was constructed by adding new shear walls and additional jacketed columns to the first strengthened building to achieve BSO requirement prescribed in FEMA 356 [2]. For all existing and strengthened buildings pushover curves were obtained and following FEMA 356, performance points at two different hazard levels, DBE and MCE were calculated and compared. Then using the procedure proposed by Adam et al. [8], SDOF models of existing and strengthened structures were constructed and nonlinear dynamic time history analyses have been performed under action of different scales of 20 ground motion records at two perpendicular directions (X and $\mathrm{Y})$. IDA curves for all buildings for each earthquake in both $\mathrm{X}$ and $\mathrm{Y}$ directions have been constructed. Limit states at each performance level have been defined. Then summarizing the multi - record IDA curves $(16 \%, 50 \%$ and $84 \%$ fractile curves) was also obtained. At the end, probabilistic structural damage estimation fragility curves were obtained in terms of peak ground acceleration (PGA) for each considered performance level.

\section{Description of the structure}

A four story reinforced concrete building representing common existing buildings in Cyprus was considered in this study. The structure was designed according to the Turkish earthquake code 2007 and it is located in the moderate 

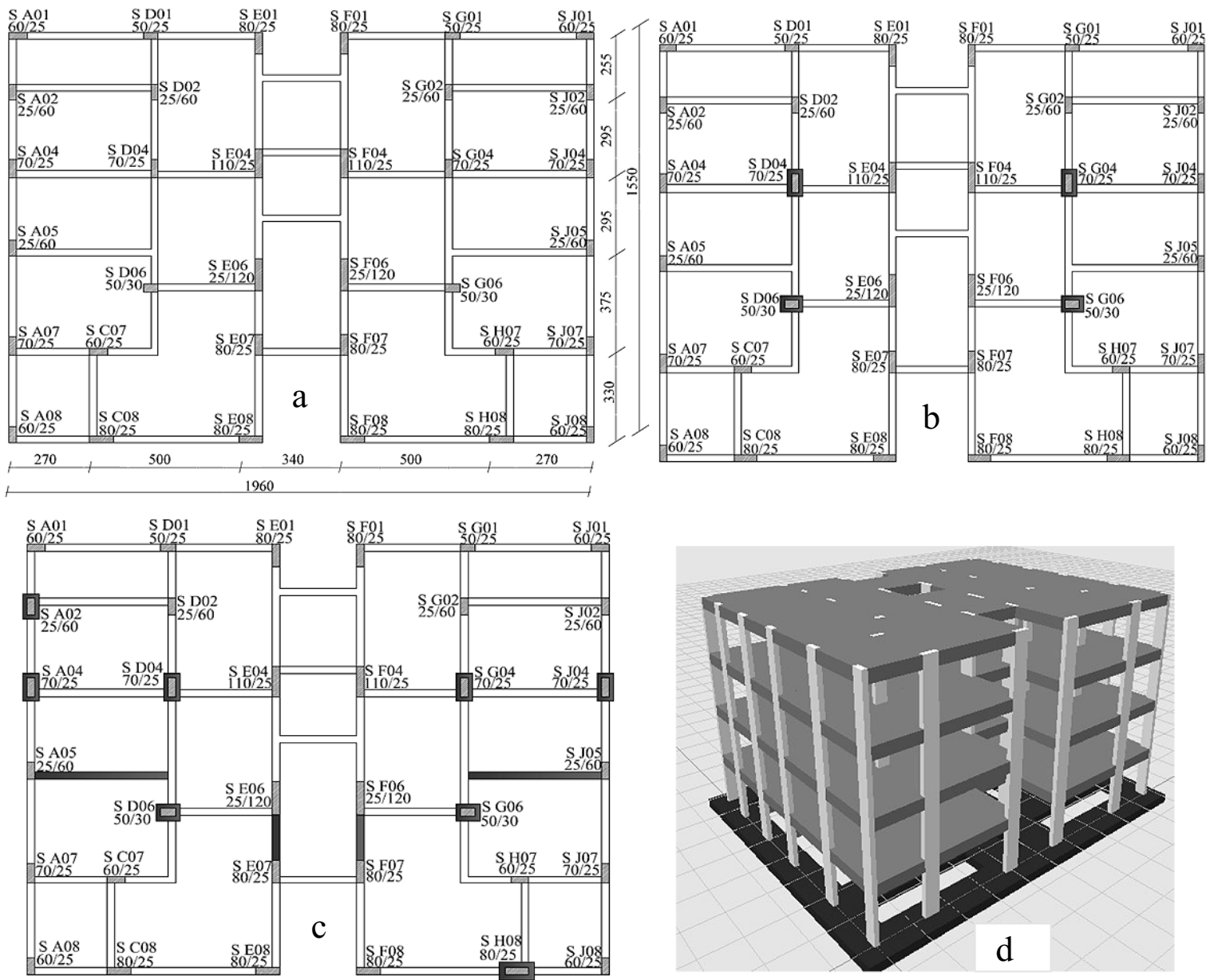

Fig. 1. Typical plan of buildings: (a) Existing; (b) Jacketed; (c) Strengthening by BSO; (d) 3D view of existing building.

seismicity region with a peak ground acceleration of $0.3 \mathrm{~g}$. The soil was a soft soil which is classified as class D in FEMA 356 [2]. Material properties were assumed to be $20 \mathrm{MPa}$ for the concrete compressive strength and $420 \mathrm{MPa}$ for the yield strength of the longitudinal and transverse reinforcement. Figure 1 shows typical plan of this building with the name and dimensions of the typical beams and columns in unit of $\mathrm{cm}$ with the typical floor height is $360 \mathrm{~cm}$.

\section{Modelling approach}

Linear and non-linear static analyses were performed by using software package program IdeCAD version 5.511 [9]. IdeCAD Structural 5 is an integrated analysis, design and detailing software for reinforced concrete constructions specially developed for structural designers of tall buildings [9]. A three dimensional model of the structure has been created to undertake the non-linear analysis. Beams, columns, slabs and foundation with their required material properties, sections and reinforcement bars were entered to the program based on the technical drawings of the existing structure. Plastic hinges properties were defined as described in FEMA 356 at both ends of the beam and column (M3 for beams and PMM for columns) as lumped plasticity.

\section{Linear static analysis}

In this study linear static analyses were performed to detect weak columns and not safety beam-column joints ba- 
Table 1

Detailed results of existing and strengthened buildings by using jacketing technique

\begin{tabular}{|c|c|c|c|c|c|c|c|c|c|}
\hline \multirow[t]{2}{*}{ Story } & \multirow[t]{2}{*}{ Col. } & \multicolumn{4}{|c|}{ Existing Structure } & \multicolumn{4}{|c|}{ Jacketed Structure } \\
\hline & & $\begin{array}{l}\text { Mra + Mru } \\
\text { (ton.m) }\end{array}$ & $\begin{array}{c}1.2(\text { Mri }+ \text { Mrj }) \\
(\text { ton.m) }\end{array}$ & $\begin{array}{c}\mathrm{Nd} \\
\text { (ton) }\end{array}$ & $\begin{array}{l}(0.10) . \text { Ac. } \\
\text { fck (ton) }\end{array}$ & $\begin{array}{c}\text { Mra + Mru } \\
\text { (ton.m) }\end{array}$ & $\begin{array}{c}1.2(\mathrm{Mri}+\mathrm{Mrj}) \\
\text { (ton.m) }\end{array}$ & $\begin{array}{c}\mathrm{Nd} \\
\text { (ton) }\end{array}$ & $\begin{array}{c}\text { (0.10). Ac } \\
\text { fck (ton) }\end{array}$ \\
\hline 1 th floor & S4D & 14 & 36 & 33 & 35 & 81 & 36 & 50 & 110 \\
\hline G.floor & S4D & 16 & 36 & 44 & 35 & 88 & 36 & 64 & 110 \\
\hline 1th floor & S4G & 14 & 36 & 33 & 35 & 81 & 36 & 50 & 110 \\
\hline G.floor & S4G & 16 & 36 & 44 & 35 & 88 & 36 & 64 & 110 \\
\hline 2nd floor & S6D & 14 & 19 & 21 & 30 & 43 & 19 & 27 & 96 \\
\hline 1th floor & S6D & 16 & 19 & 31 & 30 & 77 & 19 & 40 & 96 \\
\hline G.floor & S6D & 18 & 19 & 41 & 30 & 84 & 19 & 52 & 96 \\
\hline 2nd floor & S6G & 14 & 19 & 21 & 30 & 43 & 19 & 27 & 96 \\
\hline 1th floor & S6G & 16 & 19 & 31 & 30 & 77 & 19 & 40 & 96 \\
\hline G.floor & S6G & 18 & 19 & 41 & 30 & 84 & 19 & 52 & 96 \\
\hline
\end{tabular}

Table 2

Detailed results of existing and strengthened buildings by using jacketing technique to achieve safe beam-column joints

\begin{tabular}{|c|c|c|c|c|c|c|c|c|c|c|}
\hline \multirow[t]{2}{*}{ Story } & \multirow[t]{2}{*}{ Columns } & \multirow[t]{2}{*}{ Bm1 } & \multirow[t]{2}{*}{$\mathrm{Bm} 2$} & \multicolumn{3}{|c|}{ Existing Structure } & \multicolumn{4}{|c|}{ Jacketing Structure } \\
\hline & & & & $\begin{array}{l}\mathrm{Ve}+ \\
\text { (ton) }\end{array}$ & $\begin{array}{l}\mathrm{Ve}- \\
\text { (ton) }\end{array}$ & $\begin{array}{l}\text { Vemax } \\
\text { (ton) }\end{array}$ & $\begin{array}{l}\mathrm{Ve}+ \\
\text { (ton) }\end{array}$ & $\begin{array}{l}\mathrm{Ve}- \\
\text { (ton) }\end{array}$ & $\begin{array}{l}\text { Vemax } \\
\text { (ton) }\end{array}$ & $\begin{array}{l}\text { Thickness of the } \\
\text { jacketing }(\mathrm{cm})\end{array}$ \\
\hline \multirow[t]{2}{*}{ 3th floor } & S4G & B311 & B312 & 77.53 & 75.77 & 37.5 & 75 & 73 & 182 & 15 \\
\hline & S4D & B309 & B310 & 75.77 & 77.53 & 37.5 & 73 & 75 & 182 & 15 \\
\hline \multirow[t]{2}{*}{ 2nd floor } & S4G & B211 & B212 & 77.53 & 75.77 & 37.5 & 75 & 73 & 182 & 15 \\
\hline & S4D & B209 & B210 & 75.77 & 77.53 & 37.5 & 73 & 75 & 182 & 15 \\
\hline \multirow[t]{2}{*}{ 1th floor } & S4G & B111 & B112 & 76.98 & 75.22 & 37.5 & 73 & 71 & 182 & 15 \\
\hline & S4D & B109 & B110 & 75.22 & 76.98 & 37.5 & 71 & 73 & 182 & 15 \\
\hline \multirow[t]{2}{*}{ G.floor } & S4G & B011 & B012 & 76.85 & 75.1 & 37.5 & 71 & 70 & 182 & 15 \\
\hline & S4D & B09 & B010 & 75.1 & 76.85 & 37.5 & 70 & 71 & 182 & 15 \\
\hline
\end{tabular}

sed on reference [7]. In Turkish earthquake code [7], a column is named as a weak column if both equations "(1)" and "(2)" are not satisfied. In these equations, Mra is the moment resistance calculated at the bottom of column or wall clear height; Mru is the ultimate moment resistance calculated at the top of column or wall clear height; Mrj is the ultimate moment calculated at the column or shear wall face in the right end $\mathrm{j}$ of the beam; Mri is the ultimate moment calculated at the column or shear wall face in the left end $\mathrm{i}$ of the beam; $\mathrm{Nd}$ is the factored axial force calculated under simultaneous action of vertical loads and seismic loads; Ac is the gross cross-sectional area of the column $\left(\mathrm{cm}^{2}\right)$ and fck is the characteristic compressive strength of the concrete used in the column $\left(\mathrm{kgf} / \mathrm{cm}^{2}\right)$.

$$
\begin{aligned}
& (\mathrm{Mra}+\mathrm{Mru}) \geqslant 1 \cdot 2(\mathrm{Mri}+\mathrm{Mrj}) \\
& \mathrm{Nd} \leqslant(0.10) . \text { Ac.fck }
\end{aligned}
$$

The detected weak columns of the existing structure are summarized in Table 1. This table also shows the detailed results of these columns which were strengthened using $15 \mathrm{~cm}$ jacketing to all sides of them to achieve strong column. According to Turkish earthquake code 2007 [7], if the shear force calculated in the left or right end of the beam "Ve $(+)$ or Ve $(-)$ " are less than the maximum shear force that the joint can resist "Vemax", the shear safety is satisfied, unless the beam-column joint is named as not safety beam-column joint. For the existing building, the not safety beam-column joints were detected and related columns were strengthened by using jacketing technique. Table 2 summarizes these results for the most critical quake direction, $+\mathrm{E}(\mathrm{X})$.

\section{Nonlinear static analyses}

After the strengthening of the existing building, nonlinear pushover analyses were carried out following the FEMA 356's NSP for evaluating the structural seismic response. The pushover (base shear-lateral displacement at control node) curves were established by application of gravity loads and two lateral load patterns (modal distribution and 


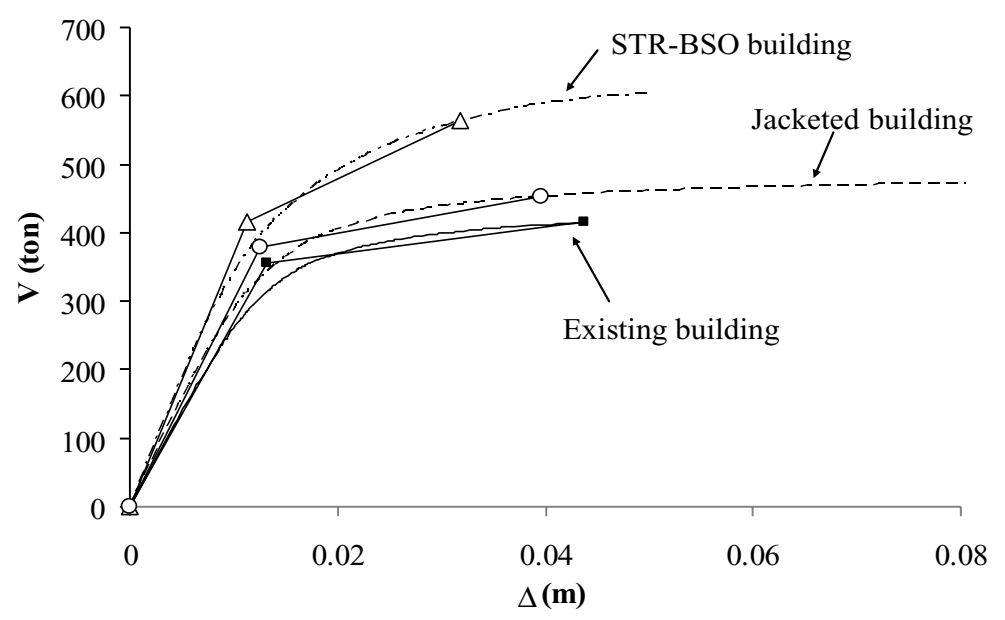

Fig. 2. Push over curves for existing and strengthened buildings in Y direction.
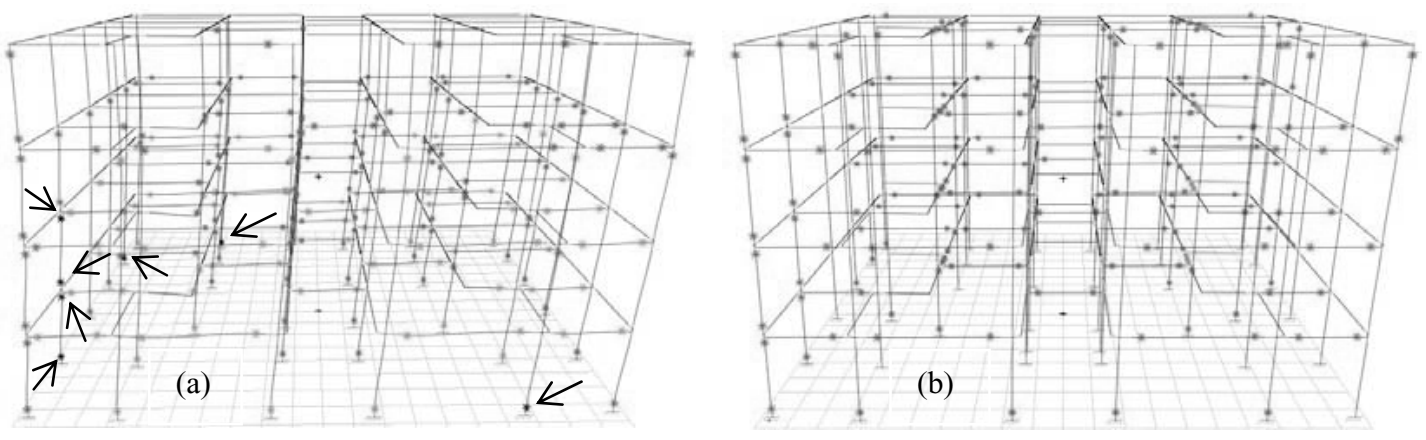

Fig. 3. Plastic hinge distributions for: (a) Existing building; (b) STR-BSO building.

uniform distribution) in both $\mathrm{X}$ and $\mathrm{Y}$ directions. The lateral load pattern with modal distribution is a vertical distribution proportional to the values of $C v x$ (vertical distribution factor) given in Eqs (3-12) of FEMA 350 while the one with uniform distribution is consisting of lateral forces at each level proportional to the total mass at each level. For instance, the + EY pushover curves of existing and jacketed building (using modal distribution load pattern) are shown in Fig. 2. As this figure shows jacketing of columns caused an increase in the initial lateral and post yielding stiffness of the existing building as well as increase in the base shear at yield point and performance point.

Based on the level of developed rotation in a plastic hinge and with respect to the acceptance criterions given in FEMA 356 [2], a plastic hinge can be located in one of the following four regions, between IO and LS, between LS and CP, between CP and collapse or after collapse. The structural demands such as base shear, roof displacement, roof drift ratio and number of hinges of different level of rotations at the performance point for two different hazard levels, DBE and MCE, were calculated and are presented in Table 3. The performance point was determined as the displacement at control node (the center of mass of the building's roof) reaches the target displacement defined in FEMA 356. Spectral accelerations at the fundamental natural period of the structure (Sa) corresponding to DBE and MCE hazard levels for the existing building were $0.75 \mathrm{~g}$ and $1.125 \mathrm{~g}$ respectively. These values were determined by comparing the design response spectrum developed in section 2.4 of Turkish earthquake code [7] and the one presented in Section 3 of FEMA 450 [10].

Buildings meeting the BSO require LS performance level for DBE hazard level and CP performance for MCE hazard level. In this study with respect to the definitions given in FEMA 356 [2] about building's LS and CP performance levels, the performance level of each building at each direction of the earthquake and selected lateral load pattern and hazard level was evaluated by considering the distribution of plastic hinges of different rotation levels in the whole structure (Fig. 3.a). Comparing the demands for existing and jacketed buildings at FEMA 356 
Table 3

Comparison of existing and strengthened buildings at FEMA 356 target displacement point

\begin{tabular}{|c|c|c|c|c|c|c|c|c|c|c|c|}
\hline \multirow[t]{2}{*}{ Build. Type } & \multirow[t]{2}{*}{ Dir. } & \multirow{2}{*}{$\begin{array}{c}\text { Latteral Load } \\
\text { Pattern }\end{array}$} & \multirow{2}{*}{$\begin{array}{c}\text { Hazard } \\
\text { Level }\end{array}$} & \multicolumn{7}{|c|}{ At FEMA356 Target Displacement } & \multirow[t]{2}{*}{$\mathrm{BSO}$} \\
\hline & & & & $\mathrm{V}$ (ton) & Dis. $(\mathrm{cm})$ & $\theta \mathrm{r}(\%)$ & \# IO-LS & \# LS-CP & $\begin{array}{c}\text { \# CP- } \\
\text { Collapse } \\
\end{array}$ & $\begin{array}{c}\#> \\
\text { Collapse }\end{array}$ & \\
\hline \multirow{16}{*}{$\begin{array}{l}\text { Original } \\
\text { Building }\end{array}$} & \multirow[t]{4}{*}{$+\mathrm{EX}$} & \multirow[t]{2}{*}{ Modal } & DBE & 277 & 7.9 & 0.645 & 93 & 0 & 0 & 3 & \multirow[t]{4}{*}{$\mathrm{NO}$} \\
\hline & & & MCE & 284 & 12.6 & 1.029 & 111 & 0 & 0 & 6 & \\
\hline & & \multirow[t]{2}{*}{ Uniform } & DBE & 310 & 7.71 & 0.63 & 84 & 0 & 0 & 3 & \\
\hline & & & MCE & 317 & 12.4 & 1.013 & 97 & 2 & 0 & 7 & \\
\hline & \multirow[t]{4}{*}{$-\mathrm{EX}$} & \multirow[t]{2}{*}{ Modal } & $\mathrm{DBE}$ & 276 & 7.93 & 0.648 & 97 & 0 & 0 & 7 & \multirow[t]{4}{*}{ NO } \\
\hline & & & MCE & 284 & 12.6 & 1.029 & 122 & 0 & 0 & 12 & \\
\hline & & \multirow[t]{2}{*}{ Uniform } & DBE & 309 & 7.73 & 0.632 & 82 & 0 & 0 & 5 & \\
\hline & & & MCE & 316 & 12.4 & 1.013 & 91 & 4 & 0 & 12 & \\
\hline & \multirow[t]{4}{*}{$+\mathrm{EY}$} & \multirow[t]{2}{*}{ Modal } & DBE & 415 & 4.38 & 0.358 & 102 & 0 & 0 & 4 & \multirow[t]{4}{*}{ NO } \\
\hline & & & MCE & 425 & 7.43 & 0.607 & 145 & 0 & 0 & 8 & \\
\hline & & Uniform & DBE & 474 & 4.15 & 0.339 & 95 & 0 & 0 & 3 & \\
\hline & & & MCE & 488 & 7.16 & 0.585 & 145 & 0 & 0 & 8 & \\
\hline & $-\mathrm{EY}$ & Modal & DBE & 415 & 4.38 & 0.358 & 102 & 0 & 0 & 4 & $\mathrm{NO}$ \\
\hline & & & MCE & 425 & 7.43 & 0.607 & 145 & 0 & 0 & 8 & \\
\hline & & Uniform & DBE & 474 & 4.14 & 0.338 & 92 & 0 & 0 & 3 & \\
\hline & & & MCE & 488 & 7.16 & 0.585 & 145 & 0 & 0 & 8 & \\
\hline Strengthened & $+\mathrm{EX}$ & Modal & DBE & 317 & 6.7 & 0.547 & 98 & 0 & 0 & 5 & $\mathrm{NO}$ \\
\hline Building-Jacketed & & & MCE & 325 & 10.8 & 0.882 & 134 & 0 & 0 & 8 & \\
\hline building & & Uniform & DBE & 366 & 6.44 & 0.526 & 90 & 0 & 0 & 3 & \\
\hline & & & MCE & 376 & 10.5 & 0.858 & 115 & 0 & 0 & 8 & \\
\hline & $-\mathrm{EX}$ & Modal & DBE & 316 & 6.71 & 0.548 & 97 & 0 & 0 & 5 & $\mathrm{NO}$ \\
\hline & & & MCE & 324 & 10.8 & 0.882 & 133 & 0 & 0 & 11 & \\
\hline & & Uniform & $\mathrm{DBE}$ & 366 & 6.45 & 0.527 & 89 & 0 & 0 & 5 & \\
\hline & & & MCE & 376 & 10.5 & 0.858 & 116 & 0 & 0 & 11 & \\
\hline & $+\mathrm{EY}$ & Modal & $\mathrm{DBE}$ & 453 & 3.96 & 0.324 & 81 & 0 & 0 & 1 & NO \\
\hline & & & MCE & 469 & 6.77 & 0.553 & 167 & 0 & 0 & 5 & \\
\hline & & Uniform & DBE & 520 & 3.68 & 0.301 & 77 & 0 & 0 & 5 & \\
\hline & & & MCE & 545 & 6.45 & 0.527 & 136 & 0 & 0 & 10 & \\
\hline & $-E Y$ & Modal & DBE & 453 & 3.96 & 0.324 & 82 & 0 & 0 & 1 & NO \\
\hline & & & MCE & 469 & 6.77 & 0.553 & 167 & 0 & 0 & 5 & \\
\hline & & Uniform & DBE & 520 & 3.68 & 0.301 & 77 & 0 & 0 & 5 & \\
\hline & & & MCE & 545 & 6.45 & 0.527 & 133 & 0 & 0 & 10 & \\
\hline Strengthened & $+\mathrm{EX}$ & Modal & DBE & 515 & 2.74 & 0.224 & 9 & 0 & 0 & 0 & YES \\
\hline Building-BSO & & & MCE & 519 & 4.89 & 0.4 & 76 & 0 & 0 & 0 & \\
\hline & & Uniform & $\mathrm{DBE}$ & 607 & 2.5 & 0.204 & 8 & 0 & 0 & 0 & \\
\hline & & & MCE & 619 & 4.52 & 0.369 & 52 & 0 & 0 & 0 & \\
\hline & $-\mathrm{EX}$ & Modal & DBE & 513 & 2.77 & 0.226 & 9 & 0 & 0 & 0 & YES \\
\hline & & & MCE & 516 & 4.94 & 0.404 & 73 & 0 & 0 & 1 & \\
\hline & & Uniform & DBE & 601 & 2.52 & 0.206 & 8 & 0 & 0 & 0 & \\
\hline & & & MCE & 615 & 4.58 & 0.374 & 53 & 0 & 0 & 1 & \\
\hline & $+\mathrm{EY}$ & Modal & DBE & 563 & 3.18 & 0.26 & 40 & 0 & 0 & 0 & YES \\
\hline & & & MCE & 610 & 5.51 & 0.45 & 116 & 0 & 0 & 0 & \\
\hline & & Uniform & $\mathrm{DBE}$ & 663 & 2.81 & 0.23 & 26 & 0 & 0 & 0 & \\
\hline & & & MCE & 711 & 5.02 & 0.41 & 142 & 0 & 0 & 0 & \\
\hline & $-\mathrm{EY}$ & Modal & DBE & 563 & 3.18 & 0.26 & 35 & 0 & 0 & 0 & YES \\
\hline & & & MCE & 610 & 5.52 & 0.451 & 173 & 0 & 0 & 0 & \\
\hline & & Uniform & $\mathrm{DBE}$ & 662 & 2.81 & 0.23 & 28 & 0 & 0 & 0 & \\
\hline & & & MCE & 590 & 7.11 & 0.581 & 143 & 0 & 0 & 0 & \\
\hline
\end{tabular}

target displacement point (Table 3) indicates that column jacketing caused an increase in the base shear, V, and a reduction in the maximum roof displacement, Dis, at both DBE and MCE hazard levels. It also caused a reduction in the roof drift ratio, $\theta \mathrm{r}$, (roof displacement/building height) such that in any load case and hazard level the roof drift ratio is less than $1 \%$. This reduction in $\theta \mathrm{r}$ caused an increase in the number of hinges which were located between IO and LS and consequently reduced their numbers which were located between LS and collapse and after collapse. Despite of these improvements in the building response, column jacketing technique did not let to the achievement of the BSO performance level. In other word, the strengthening procedure which was based on the 
Table 4

Characteristics of equivalent single degree of freedom

\begin{tabular}{cccccc}
\hline & Building type & Elastic stiffness $(\mathrm{kN} / \mathrm{m})$ & Post yield stiffness $(\mathrm{kN} / \mathrm{m})$ & Yield strength $(\mathrm{kN})$ & Building weight $(\mathrm{kN})$ \\
\hline \multirow{2}{*}{$\mathrm{EX}$} & original & 122440 & 1915 & 2510 & 11938 \\
& strengthened & 149239 & 2042 & 2940 & 12248 \\
& BSO & 433333 & 1416 & 5200 & 13009 \\
$+\mathrm{EY}$ & original & 267606 & 3076 & 3800 & 11938 \\
& strengthened & 295238 & 2953 & 4340 & 12248 \\
& BSO & 351667 & 3921 & 6330 & 13009 \\
\hline
\end{tabular}

linear static analyses for removing of both weak columns and not-safe shear column beam joints could not provide BSO performance level for existing building. Last column of Table 3 shows these results.

Therefore, the second strengthened building (named as STR-BSO) was constructed by adding new shear walls and additional jacketed columns to the first strengthened building (jacketed building) to achieve BSO requirement. To satisfy the BSO requirements, several tries were done. Figure 1 shows the plan of the strengthened building which could satisfy the BSO requirements. The structural demands for the STR-BSO building are presented in Table 3. As this table shows the base shear of STR-BSO building is much more than the jacketed building and a remarkable reduction can be seen in the maximum roof displacement of this building. However, the maximum roof displacement of STR-BSO building is less than the jacketed building, but the ductility ratio of STR-BSO building is higher than jacketed building. It is due to the reduction in the roof displacement at yield point of the STR-BSO building when compared to jacketed building (Fig. 2). Ductility ratio can be obtained by dividing the roof displacement at target displacement point by roof displacement at yield point. Table 3 also shows a remarkable reduction in the number of hinges corresponding to collapse for the STR-BSO building which finally caused this building pass the BSO requirements. Figure 3 shows the plastic hinge distribution for existing and STR-BSO buildings where no collapsed elements ( $\rightarrow$ represents collapse joints) were observed for STR-BSO building.

\section{Incremental dynamic analyses}

In order to perform incremental dynamic analyses the proposed procedure by Adam et al. [8] was used. Adam et al. [8] proposed a procedure to consider $P-\Delta$ effects in multi degree-of-freedom structures through the use of an equivalent single-degree-of-freedom system with properties defined based on the results from a pushover analysis. The underlying assumption in this procedure was that the post yielding global stiffness obtained from a pushover analysis characterizes the global or local mechanism involved when the actual structure approaches dynamic instability. Collapse was assumed to occur when a small increment in the ground motion intensity produces a large increase in the structural response. Adam et al. [8] showed that the global $P-\Delta$ effects of non deteriorating structures may be predicted with good accuracy with the proposed procedure and that in most cases the predictions error on the conservative side.

Therefore, in order to perform incremental dynamic analyses, first, pushover curves for all three structures (existing, jacketed and STR-BSO) in both X and Y directions and by considering two different lateral load pattern, were idealized as bilinear curves at a target displacement equal to $2 \%$ of the building height. Then, among them, for each building and each earthquake direction, those caused higher demands (lower elastic and inelastic stiffness and lower yield strength) were selected to be used for IDA. The characteristics of these selected idealized bilinear curves are summarized in Table 4. Previous studies conducted by Shome and Cornell [11] have shown that for low-rise to mid-rise buildings, ten to twenty records are usually enough to provide sufficient accuracy in the estimation of seismic demands, assuming a relatively efficient intensity measure, like $S a$, is used. Consequently, as was used by other researchers (e.g. Vamvatsikos [6]), IDA's were performed under an ensemble of 20 ground motions [12]. These ground motion records belong to a bin of relatively large magnitudes of 6.5-7.5 and representing both nearand far-field ground motions and all recorded on firm soil.

In this study in order to perform IDA the NONLIN software [13] was used. NONLIN is a useful tool for performing nonlinear dynamic response history analysis. NONLIN is a Microsoft Windows based application that has been developed in Visual Basic by Charney [13]. The program is capable of handling material and geometric 


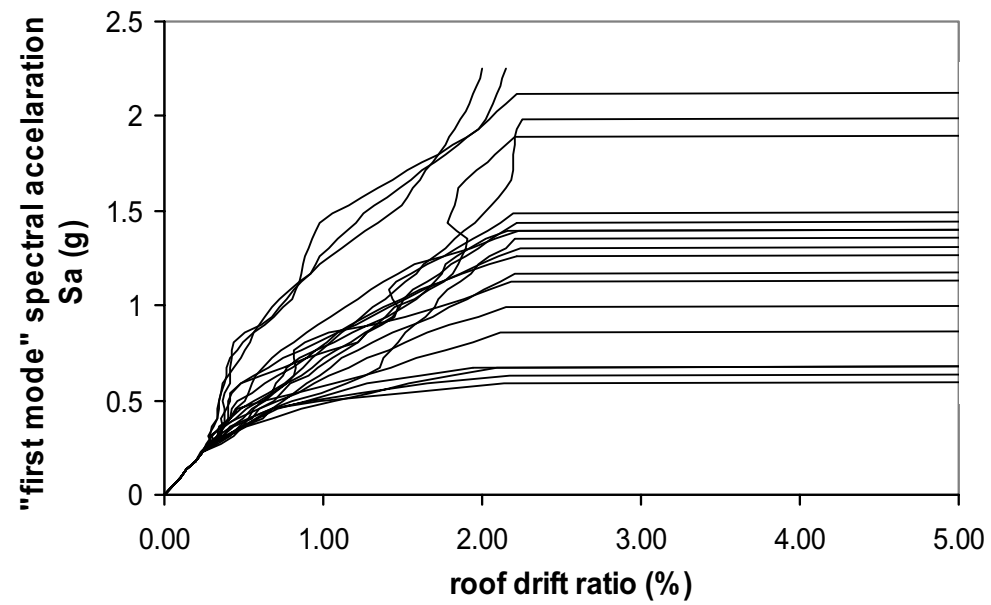

Fig. 4. IDA curves for the existing building for EX.

nonlinearities. Material nonlinearity can be taken into account by specifying yield strength and post yield stiffness (which were obtained based on idealized bilinear pushover curves, Table 4). The geometric nonlinearity can be included by activating the P-Delta option. A plot of Intensity Measure (IM) of ground motion versus Damage Measure (DM) of structural response under scaled ground motion is known as an IDA curve. The ground motions were first multiplied with a scale factor. The system's period of vibration of each building and the target pseudo acceleration ( $0.75 \mathrm{~g}$ for earthquake zone 3 and soil class $\mathrm{D})$ determined the scale factor. The common DMs can be roof drift (used in this study), inter-story drift, maximum base shear and residual deformation. Peak ground acceleration, PGA, or spectral acceleration at the fundamental natural period of the structure, Sa, are usually used as IMs. IDA curves for all buildings for each earthquake in both $\mathrm{X}$ and $\mathrm{Y}$ directions have been constructed. For instance Fig. 4 presents the IDA curves for the existing building for the $\mathrm{X}$ direction of the earthquake. In this figure, roof drift ratio was obtained by dividing the maximum roof displacement by the building height (12.25 $\mathrm{m})$. Based on the recommendations given in FEMA 356 [2], the maximum displacements obtained from the nonlinear time history analyses of equivalent SDOF models were multiplied by the factor $\mathrm{C}_{0}(1.35)$ to correlate the results of SDOF to MDOF. Figure 4 also shows that at the low level of $\mathrm{Sa}(0.3 \mathrm{~g})$, under any of records, structure shows elastic response such that the linear branch of IDA curves for all 20 records are exactly same. By increasing the Sa, the building shows a nonlinear response and based on the property of each record, the response of structure is different under a given Sa. However, for most of records, flattening occurred around $2 \%$ roof drift ratio. It might be the reason why most of seismic documents define $2 \%$ roof drift ratio as building collapse.

Summarizing the multi - record IDA curves, $16 \%, 50 \%$ and $84 \%$ fractile curves for three buildings in both $\mathrm{X}$ and $\mathrm{Y}$ directions were obtained. For instance, Fig. 5 shows these curves for existing building under EX earthquake load. As this figure shows at Sa equal to $0.75 \mathrm{~g}$ (representing DBE hazard level), $84 \%$ of records caused a roof drift ratio greater than $0.6 \%$ while $16 \%$ of records caused a drift ratio greater than $1.25 \%$. In FEMA 273 [14] the CP for reinforced concrete frames are defined as roof drift reaches $1.5 \%$ of the building height. However, according to FEMA 356 [2] for reinforced concrete wall buildings a roof drift equal to $1 \%$ and $2 \%$ of the building height are considered as LS and CP respectively. The performance limits, IO, LS and CP based on the inter-story drift are identified 1\%, 2\% and 4\% in FEMA 356. A study was done by Yakut [15] to correlate the deformation demands with ground motion intensity. In that study 16 reinforced concrete buildings which were designed based on the Turkish earthquake code were analysed under 80 different ground motions. However that study showed a strong correlation between maximum inter-story drift ratio (MIDR) and roof drift ratios (AIDR), there is still a remarkable dispersion in AIDR at a given maximum inter-story drift ratio. In current study, using the results of reference [15], a lower bound of AIDR with probability of exceeding of $90 \%$ at specific MIDRs equal to $1 \%$ (IO) and 2\% (LS) were calculated to find associated performance levels of IO and LS based on the roof drift ratio. In this case, the associated roof drift ratios corresponding to performance levels, IO and LS were $0.48 \%$ and $1.34 \%$ respectively. Table 5 summarizes the used limits for roof drift ratio at performance levels IO, LS and CP for three buildings. 
Table 5

Limits used for performance levels IO, LS, and CP based on roof drift ratio

\begin{tabular}{lccc}
\hline Building Type & IO $(\%)$ & LS (\%) & CP (\%) \\
\hline Existing and Jacketed & 0.48 & 1.34 & 2 \\
STR-BSO & 0.48 & 1 & 2 \\
\hline
\end{tabular}

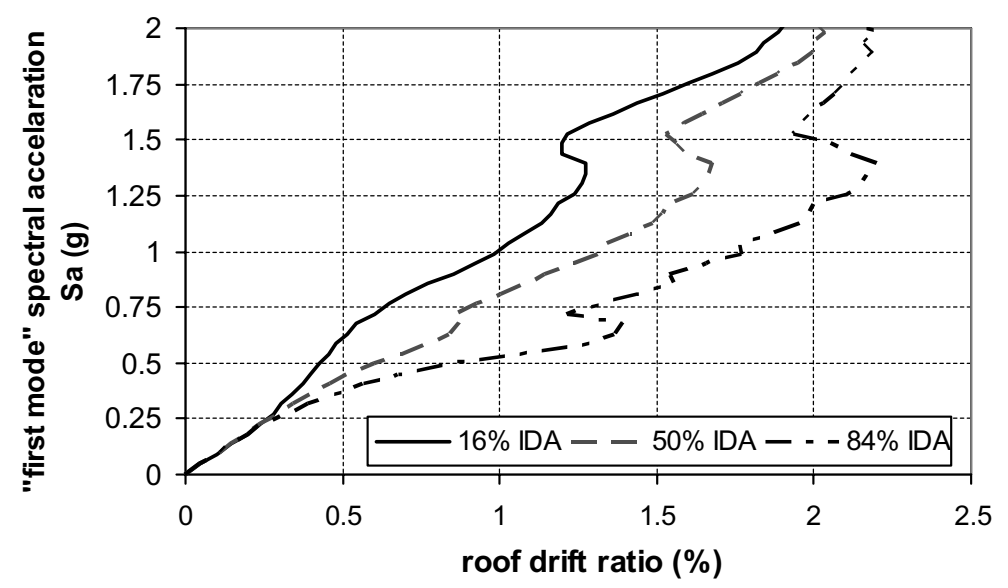

Fig. 5. Spectral acceleration vs. roof drift ratio curves for different IDA levels.

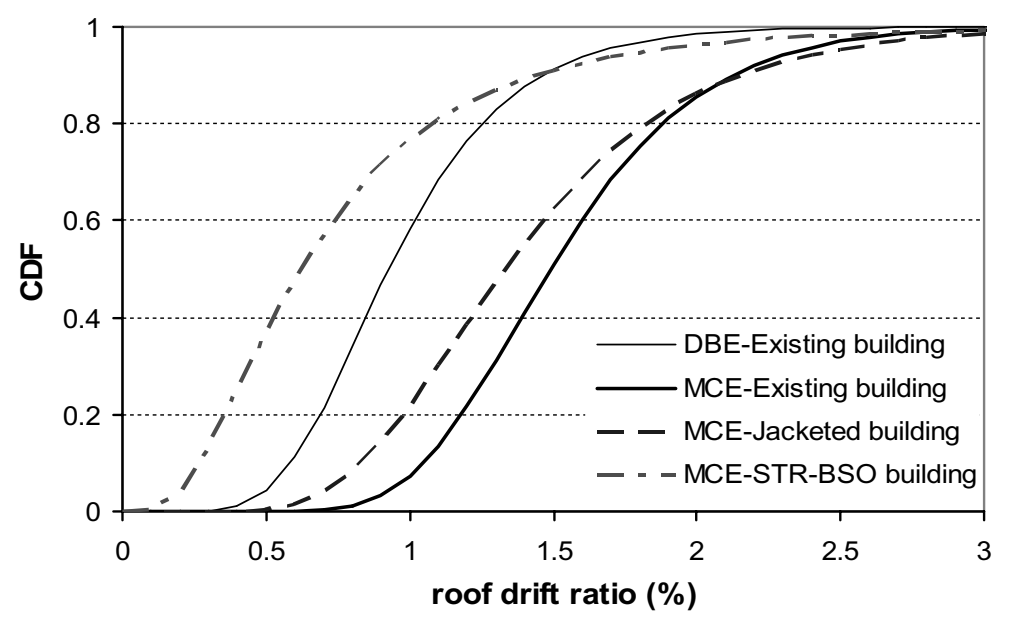

Fig. 6. CDFs for maximum roof drift ratio.

Figure 6 shows the cumulative distribution functions (CDF) for maximum roof drift ratio for existing building in $\mathrm{X}$ direction at two hazard levels, DBE and MCE. As it is expected at MCE hazard level, the probability of exceeding a roof drift ratio is higher when is compared to DBE hazard level. For instance the probabilities of exceeding $2 \%$ roof drift ratio (corresponded to CP limit state) for existing building were $1.55 \%$ and $14.3 \%$ at hazard levels DBE and MCE respectively. This figure also compares the effectiveness of two used strengthening methods at MCE hazard level. First of all comparing two strengthening techniques clearly shows that the strengthening method based on the satisfying BSO requirement is much more effective than column jacketing to reduce the probability of exceeding any roof drift ratio. Column jacketing (first strengthening method) was only effective at low level of roof drift ratio. For instance column jacketing caused a $14 \%$ reduction in the probability of exceeding of $1 \%$ roof drift ratio from 92.5 to $78.4 \%$. This reduction was only $0.5 \%$ (from 14.3 to 13.8 ) when probability of exceeding was calculated at $2 \%$ 
Table 6

Probability of exceeding of limit states IO, LS and CP for three buildings for both X and Y directions at different seismic zones

\begin{tabular}{|c|c|c|c|c|c|c|c|c|c|}
\hline \multirow[t]{3}{*}{ Building type } & \multirow[t]{3}{*}{ Limit state } & \multicolumn{4}{|c|}{ X Direction (\%) } & \multicolumn{4}{|c|}{ Y Direction (\%) } \\
\hline & & \multicolumn{4}{|c|}{ Seismic Zone-Max-PGA(g) } & \multicolumn{4}{|c|}{ Seismic Zone-Max-PGA(g) } \\
\hline & & $\mathrm{Z} 1-0.4$ & $\mathrm{Z} 2-0.3$ & Z3-0.2 & Z4-0.1 & Z1-0.4 & $\mathrm{Z} 2-0.3$ & Z3-0.2 & Z4-0.1 \\
\hline \multirow[t]{3}{*}{ Existing } & $\mathrm{IO}$ & 91.7 & 76.16 & 40.4 & 3.06 & 71 & 26.8 & 1.1 & $1.80 \mathrm{E}-05$ \\
\hline & LS & 44.8 & 19.05 & 2.7 & 0.01 & 10.8 & 2.1 & 0.08 & $1.90 \mathrm{E}-05$ \\
\hline & $\mathrm{CP}$ & 17.38 & 4.38 & 0.26 & $1.70 \mathrm{E}-04$ & 3.4 & 0.3 & $5.60 \mathrm{E}-03$ & $1.80 \mathrm{E}-07$ \\
\hline \multirow[t]{3}{*}{ Jacketed } & IO & 88 & 71.4 & 38.4 & 3.8 & 54 & 14.7 & 0.37 & $2.40 \mathrm{E}-06$ \\
\hline & LS & 43 & 21.8 & 5.2 & 0.1 & 5 & 0.57 & $7.90 \mathrm{E}-03$ & $1.70 \mathrm{E}-07$ \\
\hline & $\mathrm{CP}$ & 25.3 & 10.4 & 1.8 & 0.022 & 0.77 & 0.02 & 3.38E-05 & $2.90 \mathrm{E}-12$ \\
\hline \multirow[t]{3}{*}{ STR-BSO } & IO & 30 & 6.9 & 0.22 & $1.00 \mathrm{E}-05$ & 24.2 & 1.9 & $3.40 \mathrm{E}-03$ & $1.80 \mathrm{E}-11$ \\
\hline & LS & 2.80 & 0.1 & $9.02 \mathrm{E}-05$ & $1.00 \mathrm{E}-12$ & 0.40 & $1.60 \mathrm{E}-03$ & $1.50 \mathrm{E}-08$ & $1.30 \mathrm{E}-21$ \\
\hline & $\mathrm{CP}$ & 0.55 & 0.024 & $7.15 \mathrm{E}-05$ & $6.40 \mathrm{E}-11$ & 8.30E-04 & $3.70 \mathrm{E}-07$ & $1.90 \mathrm{E}-13$ & $1.70 \mathrm{E}-28$ \\
\hline
\end{tabular}

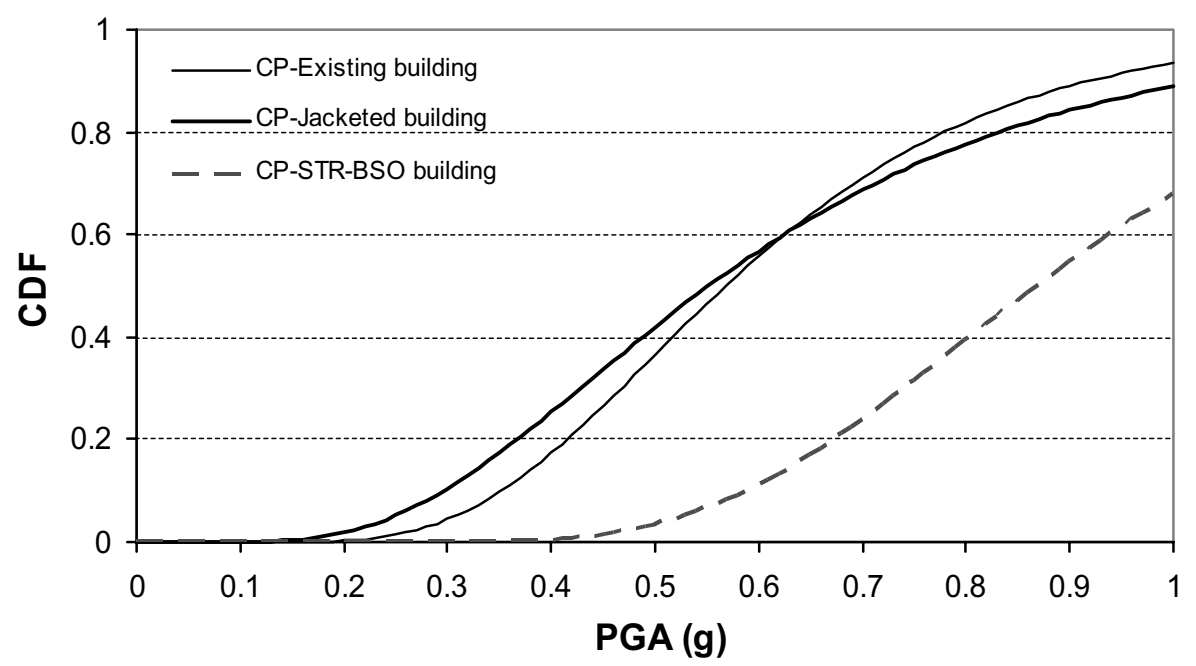

Fig. 7. Fragility curves for three buildings at $\mathrm{X}$ direction.

roof drift ratio. This figure shows that for roof drift ratios greater than 1.5\%, BSO building at MCE hazard level has approximately same probability of exceeding as existing building at DBE hazard level. In this study probabilistic structural damage estimation fragility curves for three buildings in both $\mathrm{X}$ and $\mathrm{Y}$ directions were obtained in terms of peak ground acceleration (PGA) for each limit state. An interesting result was achieved when fragility curves for existing and jacketed buildings were compared at limit states LS and CP at X direction. Unlike the expectation, at a given seismic zone (PGA), jacketed building had a higher probability of exceeding of limit states LS and CP when was compared to the existing building. For instance, Fig. 7 shows fragility curves for three buildings at $\mathrm{CP}$ performance level for $\mathrm{X}$ direction. As this figure shows for the first seismic zone (maximum PGA $=0.4 \mathrm{~g}$ ) the probabilities of exceeding of limit state CP for the existing and the jacketed buildings are $17.38 \%$ and $25.3 \%$ while this probability for BSO building is $0.55 \%$. This indicates that strengthening method based on the linear static analyses may not cause an improvement in the building performance at performance levels LS and CP. However, results showed that it can be useful only for IO performance level.

Table 6 summarizes the probability of exceeding of limit states IO, LS and CP for three buildings for both X and $\mathrm{Y}$ directions at different seismic zones. Comparing of results for both $\mathrm{X}$ and $\mathrm{Y}$ directions indicates that buildings are weaker in $\mathrm{X}$ direction such that the probability of exceeding of any limit sate at any seismic zone is higher in $\mathrm{X}$ direction when is compared to Y direction. As it is expected, by increasing the PGA the probability of exceeding of limit states increased and reduced by strengthening of the building (without considering the exceptions mentioned in previous paragraph). This Table clearly shows that strengthening based on the satisfying BSO requirements is much more effective than strengthening based on linear static procedures on the basis of removing weak columns and not safe column beam joints. 


\section{Conclusion}

This study aimed to assess the seismic structural response of a four story existing RC building. For this purpose, first, the weak structural elements (e.g. the not safety beam-column joints and weak columns) were detected using linear static procedure (LSP) analyses on the basis of Turkish earthquake code. Then, two different strengthening methods were examined. In the first method, the existing building was strengthened based on linear static procedures, using column jacketing to satisfy seismic code requirements to remove weak elements. The second strengthening method was carried out using nonlinear static procedures to achieve the basic safety objective (BSO) performance level described in FEMA 356.

Comparing demands for existing and jacketed buildings at FEMA 356 target displacement point indicated that column jacketing caused an increase in the building base shear and a reduction in the maximum roof displacement. It also caused an increase in the number of plastic hinges which were located between IO and LS and consequently caused a reduction in the number of plastic hinges which were located between LS and CP and after CP. Despite of these improvements, results showed that strengthening based on linear static procedure did not lead to achieve the BSO performance level. Whilst the strengthening of the existing building based on nonlinear static procedures was effective to provide BSO performance level.

Comparing of fragility curves for three buildings in both X and Y directions showed that the strengthening method based on the satisfying BSO requirements is much more effective than strengthening based on linear static procedures to reduce the probability of exceeding of limit states IO, LS and CP at any seismic zone. Therefore, as it is indicated by other researchers assessment and strengthening of existing buildings should be based on the nonlinear procedures rather than linear procedures to improve the performance of buildings under a severe earthquake.

\section{Acknowledgement}

The authors would like to express their sincere appreciations to the coordinator of ideCAD company Mr. Faruk Saka to provide IDECAD software program for this study.

\section{References}

[1] ATC, "The Seismic Evaluation and Retrofit of Concrete Buildings", ATC-40 Report, Applied Technology Council, Redwood City, California, Vo1. 1 and 2, 1996.

[2] FEMA, "Prestandard and commentary for the seismic rehabilitation of buildings", Prepared by the American Society of Civil Engineers for the Federal Emergency Management Agency, Washington, D.C. Publ. No. 356, 2000.

[3] R. Villaverde, Methods to assess the seismic collapse capacity of building structures: State of the art, Journal of Structural Engineering 133(1) (2007), 57-66.

[4] FEMA, "Recommended seismic design criteria for new steel moment frame buildings", Washington, D.C, Publ. No. 350, 2000.

[5] D. Vamvatsikos and C.A. Cornell, Incremental dynamic analysis, Earthquake Eng Struct Dyn 31(3) (2002), $491-514$.

[6] D. Vamvatsikos and C.A. Cornell, Applied incremental dynamic analysis, Earthquake Spectra 20(2) (2004), $523-553$.

[7] Ministry of Public Works and Settlement Government of Republic of Turkey, Specification for Structures to be Built in Disaster Areas Earthquake Disaster Prevention, 2007.

[8] C. Adam, L.F. Ibarra and H. Krawinkler, Evaluation of P-delta Effects in Non-Deteriorating MDOF Structures From Equivalent SDOF Systems, Proc., 13th World Conference on Earthquake Engineering, Vancouver, B.C., Canada, 2004, Paper No. 3407.

[9] IdeCAD Structural 5.511 Enterprise Software Program, http://www.idecad.com.tr/, 2007.

[10] FEMA, "NEHRP recommended provisions (national earthquake hazards reduction program) for seismic regulations for new buildings and other structures", FEMA 450, 2003 edition, part 1: provisions, prepared by the building seismic safety council for the federal emergency management agency building seismic safety council national institute of building sciences Washington, D.C. 2004.

[11] N. Shome and C.A. Cornell, Probabilistic seismic demand analysis of nonlinear structures, Report No. RMS-35, RMS Program, Stanford University, Stanford, 1999.

[12] Pacific Earthquake Engineering Research Center, http://peer.berkeley.edu/, 2009.

[13] F.A. Charney, NONLIN: A computer program for earthquake engineering education, The EERC-CUREe Symposium in Honor of Vitelmo V. Bertero, Berkeley, California, Berkeley: Earthquake Engineering Research Center, University of California, 1997, pp. 251-254.

[14] FEMA 273, "Federal Emergency Management Agency-NEHRP Guidelines for the Seismic Rehabilitations of Buildings", Washington D.C., USA, 1997.

[15] A. Yakut and H. Yılmaz, Correlation of Deformation Demands with Ground Motion Intensity, Journal of Structural Engineering 134(12) (2008), 1818-1828. 

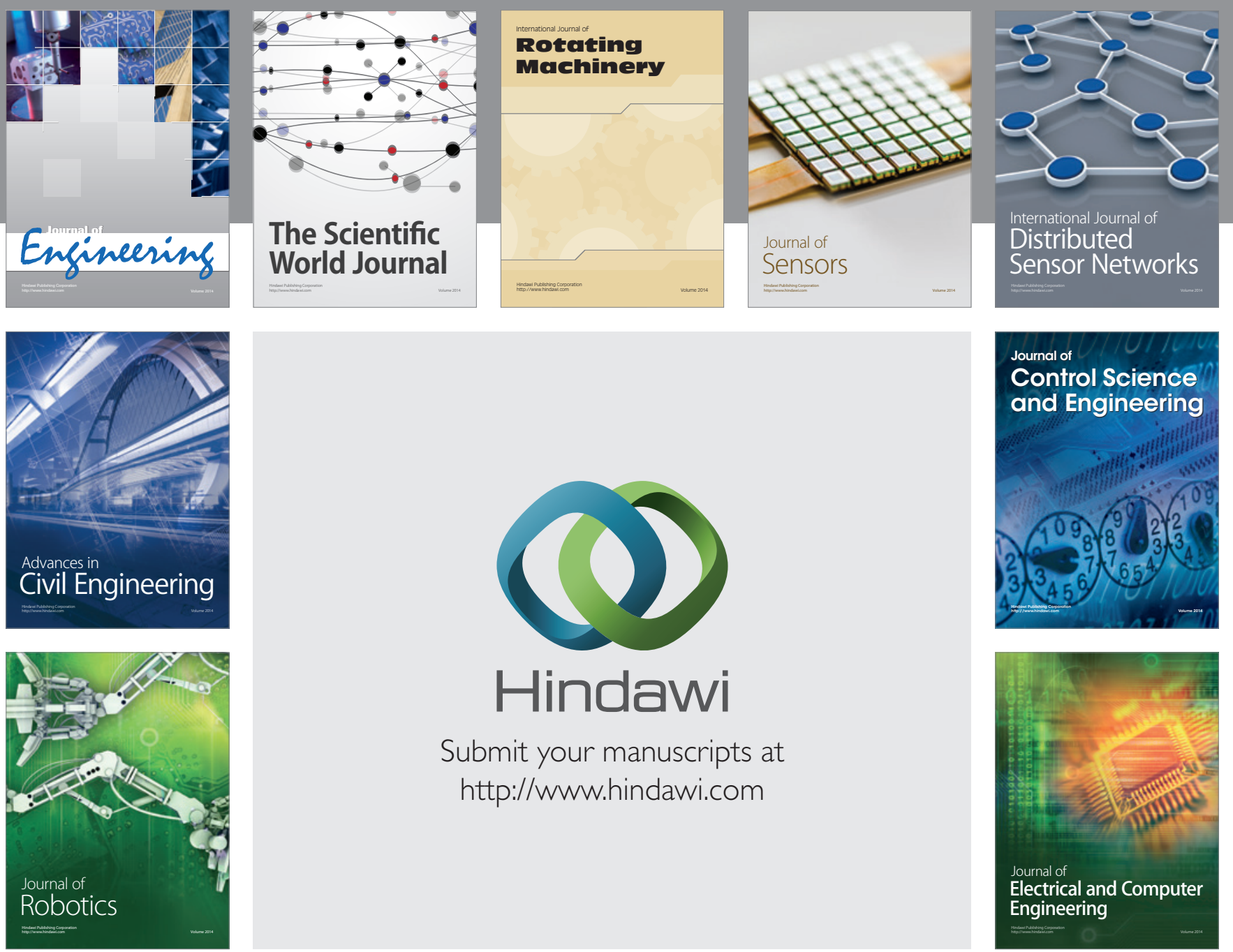

Submit your manuscripts at

http://www.hindawi.com
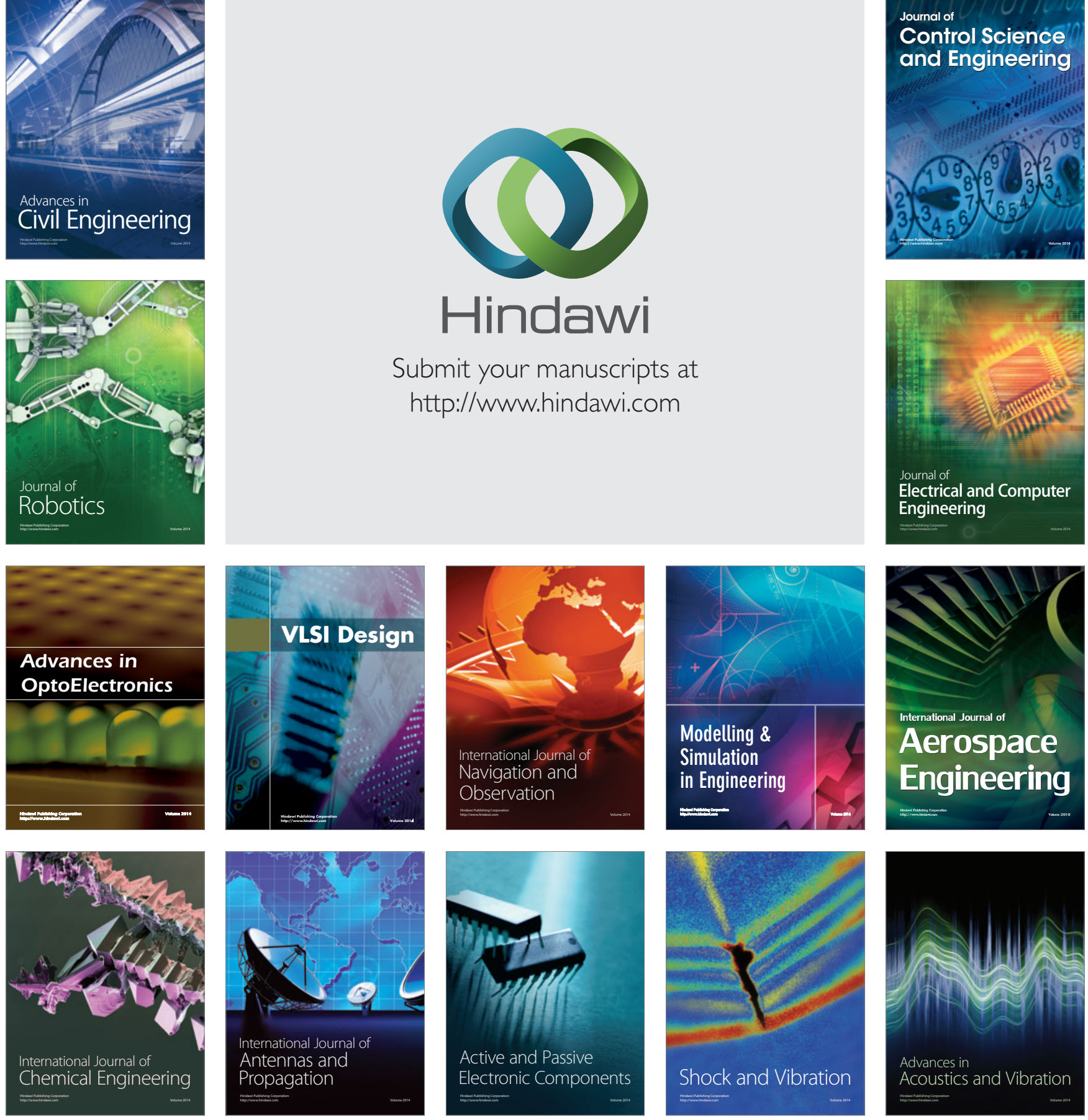